Potravinarstvo Slovak Journal of Food Sciences vol. 15, 2021, p. 961-969

https://doi.org/10.5219/1672

Received: 18 July 2021. Accepted: 24 September 2021. Available online: 28 October 2021 at www.potravinarstvo.com (C) 2021 Potravinarstvo Slovak Journal of Food Sciences, License: CC BY 4.0

ISSN 1337-0960 (online)

\title{
THE ORGANOLEPTIC QUALITY OF LIQUID FOOD FORMULA MADE FROM SNAIL (PILA AMPULLACEA), TEMPEH, AND MORINGA LEAVES
}

\author{
Fery Lusviana Widiany, Mochammad Sja'bani, Susetyowati, Emy Huriyati
}

\begin{abstract}
This study aims to determine the organoleptic quality of liquid food formula made from snail (Pila ampullacea), tempeh, and moringa (Moringa oleifera) leaves. The study was conducted in Yogyakarta, Indonesia. It involved 25 moderately trained panelists and also 5 trained panelists, who met the criteria. The measured variable was the organoleptic quality, which included aspects of color, texture, taste, and aroma. The formula tested was a powder formula made from the snail, tempeh, and moringa leaves. The proportion of snail flour, tempeh flour, and moringa leaves flour was 50:30:20. It was found that more than $50 \%$ of panelists liked the liquid food formula based on color, texture, taste, and aroma. Independent t-test to determine the difference between the organoleptic quality of the two groups showed $p=0.710$ for color, $p=0.335$ for texture, $p=0.603$ for taste, and $p=0.880$ for aroma. In conclusion, most of the panelists liked the liquid food formula products made from snail, tempeh, and moringa leaves based on the organoleptic quality result. There was no difference between the organoleptic quality studies of the two groups in the aspect of color, texture, taste, and aroma.
\end{abstract}

Keywords: liquid food formula; moringa leaves; organoleptic quality; snail (Pila ampullacea); tempeh

\section{INTRODUCTION}

Protein-energy wasting is highly prevalent in hemodialysis patients (Ikizler, 2013). Management of nutritional aspects of hemodialysis patients includes a comprehensive combination of preventive maneuvers to diminish protein and energy depletion. The recommended dietary protein and calorie intake for sedentary hemodialysis patients are $1.2-1.4$ g. $\mathrm{kg}^{-1}$ and

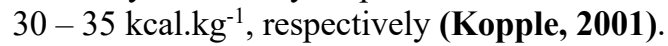

An important consideration regarding strategies for increasing dietary protein intake in hemodialysis patients is the potential for increased intake of several potentially harmful elements, especially phosphorus (Kovesdy, Shinaberger and Kalantar-Zadeh, 2010). Nutritional support for hemodialysis patients with high protein and low phosphorus content is required.

This nutritional support can be fulfilled from functional foods that utilize Indonesian local food. The making of formula from local food enables the community to optimize local food into more nutritious food so that it can be produced at the household scale (Pratiwi et al., 2021). Functional food can be in the form of natural food or food that contains one or more certain components that have a functional effect on the health and welfare of consumers (Tur and Bibiloni, 2016).

Functional foods can be made from modification of some local food ingredients in food to provide health benefits.
Several local food ingredients in Indonesia have a high protein content but meet phosphorus to protein ratio below 16, that are snail (Pila ampullacea), tempeh, and moringa (Moringa oleifera) leaves.

Pila ampullacea is a freshwater snail that is widespread in freshwater, some of which are known to be in brackish water. Snail contains higher protein and calcium but low in phosphorus than other sources of animal protein. Snail contains vitamin D3 (cholecalciferol) $21 \mu \mathrm{g} .100 \mathrm{~g}^{-1}$ edible weight. Snails have high protein content, but low phosphorus content, so they are good for giving to hemodialysis patients (Subekti, 2004).

Modification of vegetable protein can be done by utilizing tempeh which is made from Indonesian local soybean. The digestibility value of tempeh is $83 \%$ better than soybean which is only $75 \%$. Tempeh also contains isoflavones, arginine, branched-chain amino acids, linoleic acid, and linolenic acid which are higher than other vegetable protein sources (Kholidah and Pardjanto, 2011).

For the fulfillment of antioxidants, the preparation of liquid food formula is modified with the addition of Moringa oleifera leaves. Moringa is a plant that can grow quickly, live long, flower all year round, and withstand extreme heat conditions. Moringa leaves have great health benefits and are often modified into a variety of foods. Moringa leaves contain antioxidant flavonoids, ascorbic 
acid, carotenoids, and phenolics (Abdull Razis, Ibrahim and Kntayya, 2014).

Previous studies related to providing oral nutritional support to hemodialysis patients have been carried out, but there has been no research that utilizes a combination of local food based on a mixture of animal protein sources, vegetable protein sources, and vegetables as a formula for oral nutritional support for hemodialysis patients. Previous research has never been conducted on providing nutritional support to patients using a combination of three local foods at once. This oral nutritional support formula derived from a mixture of snail, tempeh, and moringa leaves has a novelty in clinical nutrition science in the dietary management of hemodialysis patients, which is suitable with the recommendations for the protein requirements from high biological value protein source can only be met by $50 \%$, while the rest is met from the vegetable protein source (Fouque, 2003).

The snail, tempeh, and moringa leaves each has weaknesses in terms of organoleptic. The snail has a fishy taste, while the tempeh and moringa leaves have an unpleasant taste and aroma. Therefore, it is necessary to analyze the organoleptic quality when these three local food ingredients are mixed into modified formulas with a certain proportion to meet the nutritional needs of hemodialysis patients. The manufacture of functional food made from local food requires an organoleptic analysis first so that it can be well received by consumers.

This study was conducted to determine the results of the organoleptic quality of liquid food formulas made with the basic ingredients of a combination of snail, tempeh, and moringa leaves. This formula was made in the form of a powder formula that can be made into liquid food. This liquid food formula will be tested on hemodialysis patients so it requires an organoleptic analysis phase first in healthy people.

\section{Scientific Hypothesis}

This project was carried out to determine the organoleptic quality of liquid food formula made from snail (Pila ampullacea), tempeh, and moringa leaves. We estimate that this liquid food formula product has a good organoleptic quality and will be liked by most of the panelists based on the aspect of color, texture, taste, and aroma. We expect that there is no difference in the organoleptic quality of liquid food formula between the moderately trained panelists and the trained panelists.

\section{MATERIAL AND METHODOLOGY \\ Samples}

The sample in this study was the liquid food formula. The formula tested was a powder formulation made from the snail, tempeh, and moringa leaves. Each ingredient was floured first, then mixed into a formula. The proportion of snail flour, tempeh flour, and moringa leaf flour in this formula was 50:30:20, and it was called the basic formula. Several food additives were added, such as corn sugar, canola oil, powder cinnamon, and rice flour. As many as 32 $\mathrm{g}$ of basic formula was mixed with $7.5 \mathrm{~g}$ of corn sugar, $8 \mathrm{~mL}$ of canola oil, $0.6 \mathrm{~g}$ of powder cinnamon, and $26 \mathrm{~g}$ of rice flour.
The study involved 25 students of the Undergraduate Nutrition Study Program of Universitas Respati Yogyakarta as moderately trained panelists who have met the inclusion criteria aged $>18$ years, liked full liquid food, did not experience taste problems, did not experience an allergy to the snail, tempeh, and moringa, and passing the food technology course. This study also involved 5 lecturers from three different universities in the Special Region of Yogyakarta, Indonesia, as trained panelists, who have an interest in nutrition and food technology.

\section{Chemicals}

Analysis of macronutrient content was carried out at the Chem-Mix Pratama Laboratory, Yogyakarta, Indonesia. Analysis of micronutrient content was carried out at the Analytical Chemistry Laboratory of Gadjah Mada University, Yogyakarta, Indonesia. Analysis of amino acid content was carried out at the PT. Saraswanti Indo Genetech Laboratory, Bogor, Indonesia. The analytical method and the nutritional content of the formula are shown in Table 1.

\section{Animals and Biological Material}

This study did not use animals or biological materials. However, the oral nutritional support formula used as a sample in this study was analyzed for germ numbers. Analysis of germ numbers was carried out at the Center for Food and Nutrition Studies, Gadjah Mada University, Yogyakarta, Indonesia.

The results of the analysis of the number of germs in the oral nutritional support formula were reported to have met the quality requirements of the drug according to the Regulation of the Head of the Food and Drug Supervisory Agency, Republic of Indonesia, namely the total plate number of bacteria of $3.05 \times 10^{3}$ colonies per $g$ (normal $\leq 10^{6}$ colonies per $\mathrm{g}$ ), yeast mold of $2.5 \times 10^{1}$ colonies per $\mathrm{g}$ (normal $\leq 10^{4}$ colonies per $\mathrm{g}$ ), and did not contain pathogenic bacteria such as Staphylococcus aureus, Salmonella, Escherichia coli, Plasmodium aeruginosa.

\section{Instruments}

The variable of this study was the organoleptic quality, which included aspects of color, texture, taste, and aroma. Organoleptic quality was defined as the result of panelist preference analysis of the taste, aroma, texture, and color of the liquid food formula product from the snail, tempeh, and moringa leaves.

The organoleptic quality was measured using a 6-point scale organoleptic test form instrument. The organoleptic quality parameters include devilish (score 1), bad (score 2), a little bad (score 3), a little good (score 4), good (score 5), and excellent (score 6).

\section{Laboratory Methods}

PT. Saraswanti Indo Genetech Bogor is an accredited testing laboratory based on ISO/IEC 17025: 2017, while the Chem-Mix Pratama Laboratory and the Analytical Chemistry Laboratory of Gadjah Mada University have not been accredited to ISO standards. The analysis method used for the nutrient content of the formula has been mentioned in Table 1.

\section{Description of the Experiment}

Sample preparation: As many as $36 \mathrm{~g}$ powder formula on each serving can be diluted with $125 \mathrm{~mL}$ hot water $\left(90-96{ }^{\circ} \mathrm{C}\right)$ to form a liquid food formula. The liquid food formula will be given in two servings a day for hemodialysis patients. 


\section{Number of samples analyzed: 1 \\ Number of repeated analyses: 2 \\ Number of experiment replication: 1 \\ Statistical Analysis}

The organoleptic quality data for each aspect were analyzed using the IBM SPSS Statistics 22 program. Data were presented as mean \pm standard deviation of the mean (SDM)

The statistical analysis was conducted to determine whether there was a difference between the organoleptic quality result of the two groups of panelists. The ShapiroWilk test was used to determine the normal distribution of the data. The result showed that the data in the two groups for all aspects were normally distributed $(p \geq 0.05)$ so that statistical analysis was carried out using an independent t-test. The hypothesis could be accepted if the result of the independent t-test showed $p \geq 0.05$.

\section{RESULTS AND DISCUSSION}

The oral nutritional support formula product made from a mixture of snail, tempeh, and moringa leaves has been analyzed for nutritional content and meets the dietary requirements for hemodialysis patients. The dietary requirements for hemodialysis patients include high protein, rich in amino acids, high in calcium, but low in phosphorus. The recommended ratio of phosphorus to protein is $<16$. If it is higher than 16, it is suspected that it can increase mortality in end-stage kidney disease (Sja'bani, 2015; Barril-Cuadrado, Puchulu and Tomero, 2013). This oral nutritional support formula has a phosphorus: protein ratio of 6.9, so it has an excellent quality based on that aspect. Although it has good nutritional content for hemodialysis patients, it is necessary to consider the organoleptic quality of the formula product so that it can be consumed by hemodialysis patients optimally.

The analysis of preference for the organoleptic aspects of the liquid food formula made from the snail, tempeh, and moringa leaves was carried out on two groups of the panelist, as well as moderately trained panelist group and trained panelist group.

The organoleptic quality result in Table 2 shows that the mean score given by the two groups of panelists on all organoleptic aspects was above 3.0, which means that the panelists liked the liquid formula product based on all organoleptic aspects. Acceptance or rejection of food depends entirely on whether it is by the expectations and needs of consumers (Mosca et al., 2015).

The frequency distribution of moderately trained panelists based on each aspect of the organoleptic quality is shown in Figure 1. It was found that most of the moderately trained panelists like liquid food formula products made from the snail, tempeh, and moringa leave based on aspects of color, texture, taste, and aroma. However, a small proportion of panelists did not like the formula product. Panelists who did not like the formula product considered that there were still weaknesses in several aspects of the organoleptic test. These weaknesses include the color of the product which was considered too dark, the texture that was still slightly thick after dissolving it with hot water, there was still a little fishy taste and bitter after-taste, and a slightly unpleasant aroma in the formula product.
Meanwhile, the organoleptic quality on the trained panelists showed slightly different results from the moderately trained panelists. The frequency distribution of trained panelists based on each aspect of the organoleptic quality is shown in Figure 2.

Figure 2 shows that most of the trained panelists liked the liquid food formula product made from the snail, tempeh and moringa leaves based on the aspects of color, taste, and aroma, but did not like the texture of the formula product. However, in the assessment of the texture aspect, $20 \%$ of the panelists chose the excellent category. A small proportion of panelists who did not like formula products based on several organoleptic aspects regarding the weaknesses of the formula product, that were the color of the product was considered too dark, the texture was still slightly thick after dissolving with hot water, there was still a little fishy taste and after-taste bitter, and a little unpleasant aroma in formula products.

The researchers continued to carry out the analysis to determine whether there was a difference between the organoleptic quality result of the two groups of the panelist. Figure 3 shows that statistically, there is no difference in the organoleptic quality based on color, texture, taste, and aroma of the liquid food formula product in the two groups of panelists $(p \geq 0.05)$, which is shown with $p=0.710$ for color, $p=0.335$ for texture, $p=0.603$ for taste, and also $p=0.880$ for aroma.

The most important component of food for the consumer is its sensory characteristics, including taste, aroma, color, texture, and overall acceptance (Aberoumand, 2015). Sensory characteristics, including taste, aroma, texture, and appearance of food specifically influence consumer decisions about food material preferences (Kostyra et al., 2016).

\section{Color}

Color is a very important component in determining the quality and degree of acceptance of food. Food that is considered delicious and has a good texture will not be eaten if it has an unsightly color or has deviated from the color it should have. Determination of food quality depends on several factors, but before other factors are considered visually, the color factor appears first to determine its quality (Winarno, 2002). The function of the color of food, the product is very important because it can affect consumer tastes and be able to arouse appetites (Rahmayanti, Ningtyias and Baroya, 2020).

Most of the panelists like the color of liquid food formula products in this study. The product's color is blackish brown like coffee. Most of the panelists prefer the food they like. Since ancient times, certain types of food have been consumed specifically because of the pleasures they offer consumers, such as ice cream, coffee, alcohol, and chocolate. These foods are usually consumed to provide a positive state of mind or to reduce negative thought states (Kim, Lee and Kim, 2016).

A small proportion of panelists disliked the color of the liquid food formula products in this study because they preferred lighter colors. In the manufacture of liquid food formula products, the formation of brown color is caused by chemical changes that occur during the process of processing the formula, namely the browning reaction. 
Table 1 The daily nutritional content of the formula.

\begin{tabular}{|c|c|c|c|}
\hline Nutrients & Unit & $\begin{array}{c}\text { Content per } 100 \mathrm{~g} \text { of edible } \\
\text { weight }\end{array}$ & Analysis method \\
\hline Energy & kcal & 259.78 & $\begin{array}{l}\text { Total energy from protein, fat and } \\
\text { carbohydrate }\end{array}$ \\
\hline Protein & $\mathrm{g}$ & 16.37 & Micro kjeldahl \\
\hline Fat & $\mathrm{g}$ & 6.23 & Soxhlet extraction \\
\hline Carbohydrate & $\mathrm{g}$ & 34.68 & By different \\
\hline Calsium & $\mathrm{mg}$ & 1538.32 & Atomic absorption spectrophotometry \\
\hline Iron & $\mathrm{mg}$ & 10.43 & Atomic absorption spectrophotometry \\
\hline Sodium & $\mathrm{mg}$ & 53.57 & Atomic absorption spectrophotometry \\
\hline Potassium & $\mathrm{mg}$ & 141.28 & Atomic absorption spectrophotometry \\
\hline Phosphorus & $\mathrm{mg}$ & 112.18 & UV-visual spectrophotometry \\
\hline Vitamin D3 & $\mu \mathrm{g}$ & $<0.67$ & 18-5-1/MU/SMM-SIG (HPLC) \\
\hline Glutamic acid & g & 2.1 & 18-5-17/MU/SMM-SIG (UPLC) \\
\hline Aspartic acid & $\mathrm{g}$ & 1.1 & 18-5-17/MU/SMM-SIG (UPLC) \\
\hline Arginine & $\mathrm{g}$ & 2.2 & 18-5-17/MU/SMM-SIG (UPLC) \\
\hline Leucine & g & 1.7 & 18-5-17/MU/SMM-SIG (UPLC) \\
\hline Glycine & $\mathrm{g}$ & 1.4 & 18-5-17/MU/SMM-SIG (UPLC) \\
\hline Alanine & $\mathrm{g}$ & 0.9 & 18-5-17/MU/SMM-SIG (UPLC) \\
\hline Lysin & g & 0.6 & 18-5-17/MU/SMM-SIG (UPLC) \\
\hline Valine & $\mathrm{g}$ & 1.0 & 18-5-17/MU/SMM-SIG (UPLC) \\
\hline Proline & $\mathrm{g}$ & 0.9 & 18-5-17/MU/SMM-SIG (UPLC) \\
\hline Serine & $\mathrm{g}$ & 1.3 & 18-5-17/MU/SMM-SIG (UPLC) \\
\hline Tryptophan & $\mathrm{g}$ & 0.1 & 18-5-63/MU/SMM-SIG (HPLC) \\
\hline Isoleucine & $\mathrm{g}$ & 0.9 & 18-5-17/MU/SMM-SIG (UPLC) \\
\hline Phenylalanine & g & 1.7 & 18-5-17/MU/SMM-SIG (UPLC) \\
\hline Tyrosine & g & 1.1 & 18-5-17/MU/SMM-SIG (UPLC) \\
\hline Histidine & g & 0.7 & 18-5-17/MU/SMM-SIG (UPLC) \\
\hline Cystine & g & 0.2 & 18-12-38/MU/SMM-SIG (LC MS/MS) \\
\hline Methionine & g & 0.2 & 18-12-38/MU/SMM-SIG (LC MS/MS) \\
\hline Threonine & $\mathrm{g}$ & 1.2 & 18-5-17/MU/SMM-SIG (UPLC) \\
\hline
\end{tabular}

Table 2 The result of organoleptic quality between two groups of panelist.

\begin{tabular}{lcccc}
\hline \multirow{2}{*}{ The aspect of the organoleptic } & \multicolumn{2}{c}{ Moderately trained panelist group } & \multicolumn{2}{c}{ Trained panelist group } \\
\cline { 2 - 5 } quality & $\mathbf{n}$ & Mean (SDM) & $\mathbf{n}$ & Mean (SDM) \\
\hline Color & 25 & $4.1(0.8)$ & 5 & $4.2(0.8)$ \\
Texture & 25 & $3.9(0.7)$ & 5 & $3.6(0.9)$ \\
Taste & 25 & $3.8(0.8)$ & 5 & $4.0(0.7)$ \\
Aroma & 25 & $3.8(0.9)$ & 5 & $3.8(0.4)$ \\
\hline
\end{tabular}


Browning in liquid food formula products is due to the Maillard reaction, lipid oxidation, and interactions between amino acids and lipid oxidation products (Agustini et al., 2014).

The browning reaction is an important reaction that occurs during the food processing process. The accumulation of brown pigment is an indication that shows the Maillard reaction to foods containing protein and carbohydrates. Besides causing browning, the Maillard reaction also affects the flavor, texture, and taste of the food through protein cross-linking and degradation (Agustini et al., 2015).

Foodstuffs that have undergone processing or heating can be expected to experience color changes. The process of heating or drying, food changes its physical and chemical quality (Utami, Fitrianingrum and Haryani, 2012). The protein content in food can cause a brown color when drying or heating (Noviyanti, Wahyuni and Syukri, 2016). This liquid food formula product has a high protein content so that the color of the product becomes dark brown.

\section{Texture}

Food texture is largely determined by the content of water, fat, protein, and carbohydrates. The texture is a pressure sensor that can be observed with the mouth (when bitten, chewed, and swallowed) or touched with fingers (Noviyanti, Wahyuni and Syukri, 2016). In this study, texture observation was carried out by determining the sensory texture based on the pressure on the liquid food formula when touched using a spoon. The texture of this liquid food formula product is slightly thick.

Most of the panelists like liquid food formula products with a slightly thick texture. The slightly thick texture is made because the formula product will be given to hemodialysis patients, which must limit the consumption of fluids. A small proportion of respondents considered the texture less watery, so they did not like liquid food formula products based on texture.

The texture or thickness of the liquid food formula is one of the parameters that determine the quality of the product. This formula product is consumed by drinking so that the respondents assume that the texture of the product must be thin and easy to swallow. However, with the consideration that the liquid food formula must be made with liquid restrictions, then $1 \mathrm{cc}$ of liquid food must contain more than $1 \mathrm{kcal}$ of energy. So that the texture of the formula product is made slightly thick.

The presence of protein content in the raw materials of snail, tempeh, and moringa leaves also affects the texture of the liquid food formula product in this study. Protein has hydration properties that can increase the absorption of water in products (Rauf, 2015).

\section{Taste}

Taste is the most important factor in determining the decision for consumers to accept or reject a food or food product. Even though the other params are good if the taste is bad or disliked the product will be rejected. There are four basic types of taste recognized by humans, namely salty, sour, sweet, and bitter. Whilst the other flavors are a combination of other tastes (Soekarto, 2012).

Taste refers to the proximal sense that requires direct contact of food with stimuli on the tongue to determine the quality of the food being digested. Basic flavors such as umami, sour, sweet, bitter, and salty are important for signaling nutrient-rich foods. The sweet taste concludes a high concentration of carbohydrates, particularly monosaccharides, whilst salty and savory tastes are associated with protein and electrolytes (Romagny, Ginon and Salles, 2017).

Most of the panelists like the taste of liquid food formula products. The organoleptic analysis showed that a small proportion of panelists did not like the taste of the product. Some comments that if judged in terms of taste, liquid food formula products have an after taste (a little bit bitter). This is because this liquid food formula product uses raw materials for tempeh and moringa leaves which are floured.

Powdered tempeh has a greater unpleasant aroma and causes a bitter after-taste in liquid food formula products. The bitter after-taste can be caused by the hydrolysis of amino acids that occurred in the Maillard reaction during the process of making tempeh flour. There are amino acids that cause a bitter taste such as lysine, arginine, proline, phenylalanine, and valine. The amino acid lysine is an amino acid that has the most bitter taste compared to other amino acids that cause a bitter taste. The compound causing the bitter taste is found in the crude fat fraction. This crude oil has a high acid, peroxide, and thiobarbituric acid (TBA) number, so it is suspected that the cause of the bitter taste is compounded resulting from degradation/oxidation of triglycerides (Kurniawati and Ayustaningwarno, 2012).

The bitter taste of tempeh flour is caused by the presence of glycoside compounds in soybean seeds. Among these glycosides, soyasaponins and sapogenins are the main causes of bitter taste in soybeans and their processed products. Other glycosides that cause off-flavor in soybeans are isoflavones and their aglycone groups. Isoflavone compounds in soy consist of genistin and daidzin, whilst the aglycone groups are called genistein and daidzein, respectively (Santoso, 2009).

Researchers have made several efforts to minimize the bitter after-taste of liquid food formula products. Among them, steaming raw tempeh before processing it into tempeh flour to reduce the bitter taste of the resulting tempeh flour, blanching raw moringa leaves for 5 minutes using hot water with temperature $\left( \pm 80-90{ }^{\circ} \mathrm{C}\right)$, and adding corn sugar to the formula. The concentration of sugar affects the taste caused by food products, the more the concentration of sugar, the more it can mask the bitter taste of moringa flour (Dewi, Suliasih and Garnida, 2016). However, based on the results of the organoleptic analysis, there were comments that there was still a little after-taste. bitter in liquid food formula products.

The effect of taste on food acceptance is highly correlated with the personal preferences that people have (Cho et al., 2015). People tend to accept and consume foods that contain a concentration of the taste they like (Kim et al., 2018). The difference in the sensation that occurs between panelists can be caused by differences in sensation received, due to differences in the level of sensitivity of the sensing organs, or due to a lack of knowledge of certain tastes (Setyaningsih and Apriyantono, 2010). 


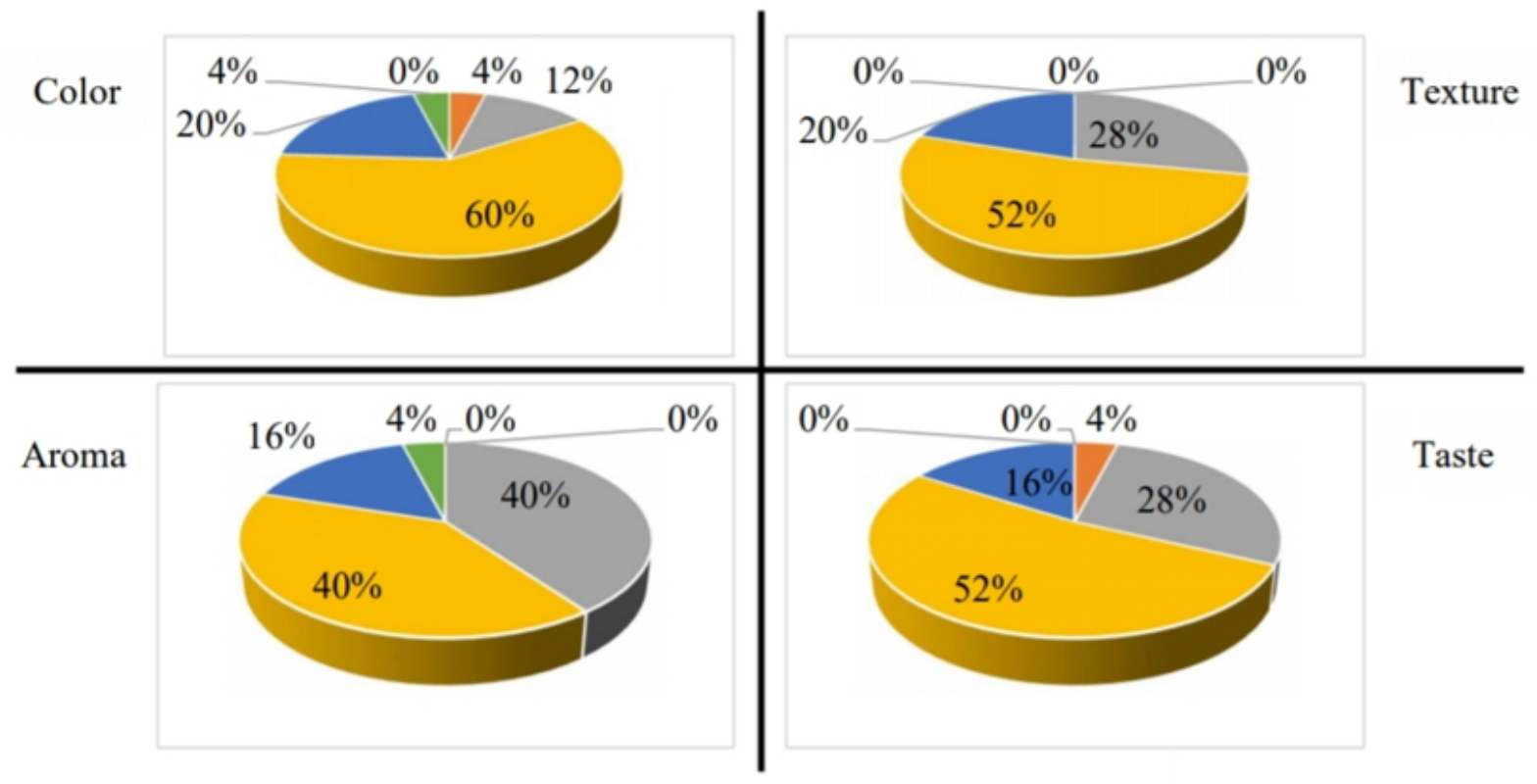

- Devilish = Bad = A little bad " A little good = Good " Excellent

Figure 1 The organoleptic quality result of liquid food formula in the moderately trained panelist group.

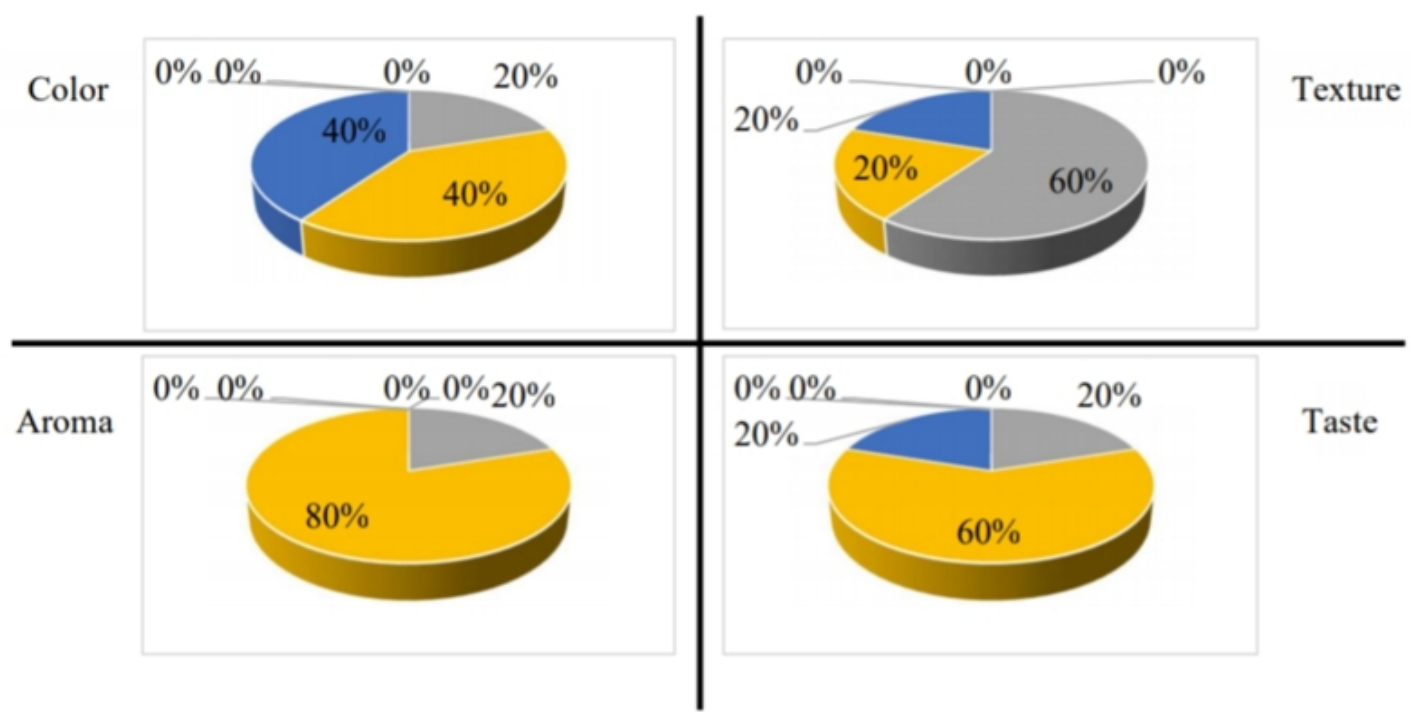

- Devilish " Bad = A little bad "A little good = Good " Excellent

Figure 2 The organoleptic quality result of liquid food formula in the trained panelist group. 


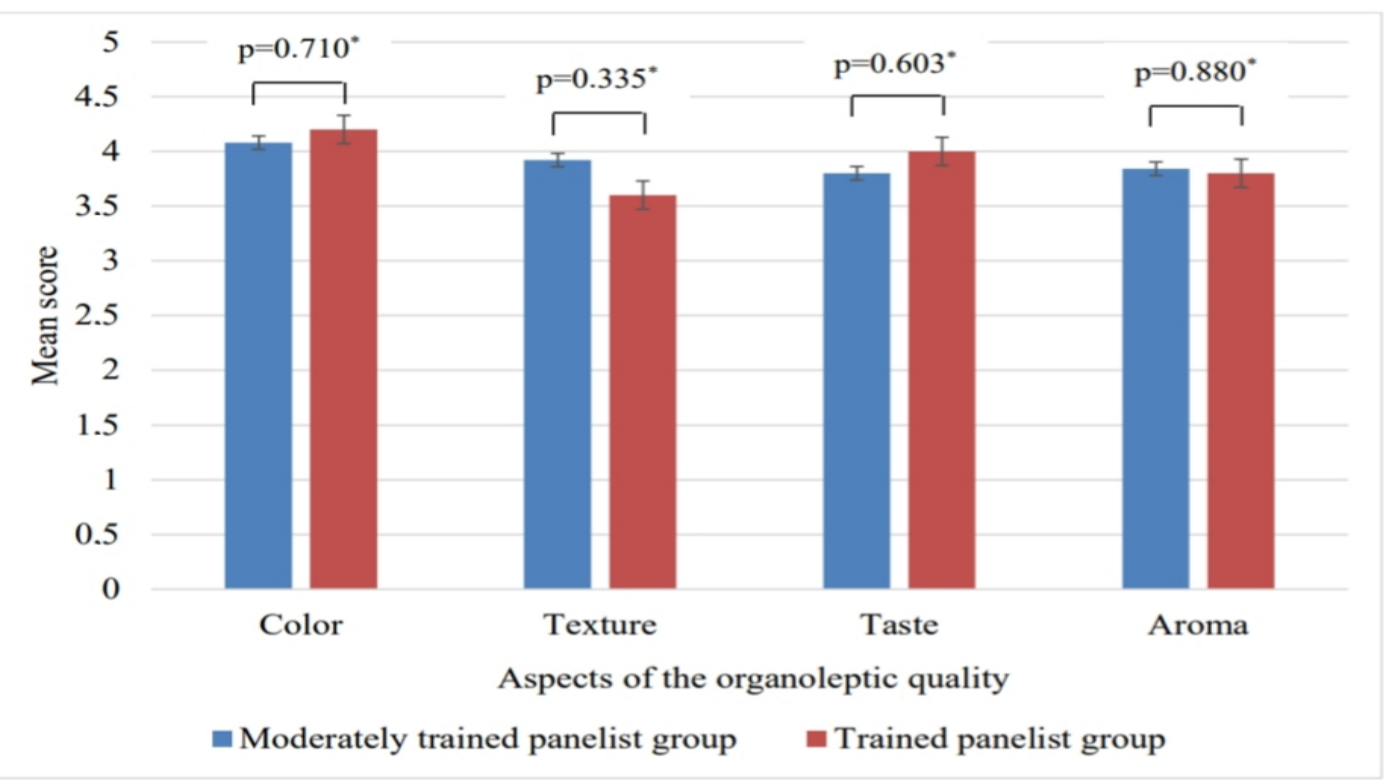

Figure 3 The difference in mean score of the organoleptic quality result in the two panelist groups. Note: * $p-$ analyzed using independent t-test.

\section{Aroma}

Aroma determines the delicacy and taste of food. The smell produced from food determines the delicacy of these foods and has to do with the five senses of smell. Aroma has a very important role in determining the degree of assessment and quality of food (Noviyanti, Wahyuni and Syukri, 2016).

The appearance of an aroma or odor is due to the presence of volatile and odorous substances. The protein contained in the material will be degraded into amino acids by the presence of heat. The reaction between amino acids and sugar will produce an aroma, whilst the fat in the material will be oxidized and broken down by heat so that some of the active ingredients caused by the breakdown will react with amino acids and peptides to produce aroma (Mutiara, Adikahriani and Wahidah, 2012).

The smell of food forms important sensory signals and a fundamental component of taste perception and shapes the way people perceive the taste and texture of these foods. Aroma serves as a signal of edible or inedible food, even before consumers see the food (Sinesio et al., 2018). The smell of food directs acceptance towards food which is specifically marked by smell (Maina, 2018).

The results of this study indicated that $60 \%$ of panelists liked the aroma of liquid food formula products. A small proportion of panelists did not like the aroma because it still had a slightly unpleasant and fishy aroma. Exposure to retro-nasal aromas has a consistent effect on food acceptability (Tauferova et al., 2015).

The aroma formation of liquid food formula products is thought to be influenced by the raw materials used to make liquid food formula products, which are snail, tempeh, and moringa leaves. The use of snail with the largest proportion compared to tempeh and moringa leaves causes the distinctive aroma of liquid food formula products which is still slightly fishy. However, the use of tempeh and moringa leaves causes an unpleasant aroma to the products produced.
Researchers have made efforts to add corn sugar and a little powder cinnamon to cover up the unpleasant smell, but based on the comments on the organoleptic quality results, it turns out that there was still a slightly unpleasant smell in liquid food formula products. The unpleasant odor of tempeh flour is produced by the presence of lipoxidase enzymes in soybeans. This occurs because the lipoxidase enzyme hydrolyzes or breaks down soybean fat into compounds that cause unpleasant odors, which are classified in the hexanal and hexanol groups. These compounds in low concentrations can cause unpleasant odors (Santoso, 2009).

\section{CONCLUSION}

The liquid food formula made from a mixture of the snail, tempeh, and moringa leaves meets the requirements of the hemodialysis diet and has good organoleptic quality based on aspects of color, texture, taste, and aroma.

It is necessary to conduct clinical trial research on providing an oral nutritional support formula made from a mixture of snail, tempeh, and moringa leaves to hemodialysis patients in hospitals. It is necessary to investigate the effectiveness of this oral nutritional support formula on clinical outcomes, nutritional status, immune status, and inflammatory status of hemodialysis patients.

\section{REFERENCES}

Abdull Razis, A. F., Ibrahim, M. D., Kntayya, S. B. 2014. Health benefits of Moringa oleifera. Asian Pacific Journal of Cancer Prevention, vol. 15, no. 20, p. 8571-8676. https://doi.org/10.7314/APJCP.2014.15.20.8571

Aberoumand, A. 2015. Production and evaluation of organoleptic characteristics of fruit juice and low-sugar pulp of Behbahan variety dates of Kasi and Kabkab. African Journal of Food Science, vol. 9, no. 5, p. 322-325. https://doi.org/10.5897/AJFS2015.1303 
Agustini, S., Priyanto, G., Hamzah, B., Santoso, B., Pambayun, R. 2014. Changes on the physical-chemical properties of kue delapan jam on various steaming time. International Journal of Science and Engineering, vol. 7, no. 2, p. 161-165. https://doi.org/10.12777/ijse.7.2.161-165

Agustini, S., Priyanto, G., Hamzah, B., Santoso, B., Pambayun, R. 2015. Pengaruh modifikasi proses terhadap kualitas sensoris kue delapan jam (A need to modify the quality of the sensor sensor to select it). Jurnal Dinamika Penelitian Industri, vol. 26, no. 2, p. 107-115. (In Indonesian)

Barril-Cuadrado, G., Puchulu, M. B., Tomero, J. A. S. 2013. Table showing dietary phosphorus/protein ratio for the Spanish population. Usefulness in chronic kidney disease. Nefrologia, vol. 33, no. 3, p. 362-371.

Dewi, F. K., Suliasih, N., Garnida, Y. 2016. Pembuatan cookies dengan penambahan tepung daun kelor (Moringa oleifera) pada berbagai suhu pemanggangan (Making cookies with the addition of Moringa leaf flour (Moringa oleifera) at various roasting temperatures). (In Indonesian) Available at: http://repository.unpas.ac.id

Fouque, D. 2003. Nutritional requirements in maintenance hemodialysis. Advances in Renal Replacement Therapy, vol. 10, no. 3, p. 183-193. https://doi.org/10.1053/j.arrt.2003.08.007

Cho, S., Yoon, S. H., Min, J., Lee, S., Tokar, T., Lee, S. O., Seo, H. S. 2015. Variations in US consumers' acceptability of korean rice cake, Seolgitteok, with respect to sensory attributes and nonsensory factors. Journal of Food Science, vol. 81, no. 1, p. S199-207. https://doi.org/10.1111/1750-3841.13153

Ikizler, T. A. 2013. Optimal nutrition in hemodialysis patients. Advances in Chronic Kidney Disease, vol. 20, no. 2, p. 181-189. https://doi.org/10.1053/j.ackd.2012.12.002

ISO/IEC 17025:2017. 2017. General requirements for the competence of testing and calibration laboratories.

Kholidah, D., Pardjanto, E. 2011. Pengaruh pemberian makanan F100 dengan bahan substitusi tepung tempe terhadap status protein pasien anak dengan gizi kurang (The effect of feeding F100 with tempeh flour substitution on the protein status of children with malnutrition): thesis. Yogyakarta, Indonesia : Universitas Gadjah Mada. (In Indonesian)

Kim, H. J., Chung, S. J., Kim, K. O., Nielsen, B., Ishii, R., O'Mahony, M. 2018. A cross-cultural study of acceptability and food pairing for hot sauces. Appetite, vol. 123, p. 306-316. https://doi.org/10.1016/j.appet.2018.01.006

Kim, S. E., Lee, S. M., Kim, K. O. 2016. Consumer acceptability of coffee as affected by situational conditions and involvement. Food Quality and Preference, vol. 52, p. 124132. https://doi.org/10.1016/j.foodqual.2016.04.008

Kopple, J. D. 2001. National kidney foundation K/DOQI clinical practice guidelines for nutrition in chronic renal failure. American Journal of Kidney Diseases, vol. 37, no. 1, p. S66S70. https://doi.org/10.1053/ajkd.2001.20748

Kostyra, E., Wasiak-Zys, G., Rambuszek, M., WaszkiewiczRobak, B. 2016. Determining the sensory characteristics, associated emotions and degree of liking of the visual attributes of smoked ham. A multifaceted study. LWT-Food Science and Technology, vol. 65, p. 246-253. https://doi.org/10.1016/j.lwt.2015.08.008

Kovesdy, C. P., Shinaberger, C. S., Kalantar-Zadeh, K. 2010. Epidemiology of dietary nutrient intake in ESRD. Seminars in Dialysis, vol. 23, no. 4, p. 353-358. https://doi.org/10.1111/j.1525-139X.2010.00745.x

Kurniawati, K., Ayustaningwarno, F. 2012. Pengaruh substitusi tepung terigu dengan tepung tempe dan tepung ubi jalar kuning terhadap kadar protein, kadar $\beta$-karoten, dan mutu organoleptik roti manis (Effect of substitution of wheat flour with tempeh flour and yellow sweet potato flour on protein content, -carotene content, and organoleptic quality of sweet bread). Journal of Nutrition College, vol. 1, no. 1, p. 344-351. (In Indonesian) https://doi.org/10.14710/jnc.v1i1.511

Maina, J. W. 2018. Analysis of the factors that determine food acceptability. The Pharma Innovation, vol. 7, no. 5, p. 253-257. Available at: https://www.thepharmajournal.com/archives/?year=2018\&vol $=7 \&$ issue $=5 \&$ ArticleId $=2049$

Mosca, A. C., van de Velde, F., Bult, J. H. F., van Boekel, M. A. J. S., Stieger, M. 2015. Taste enhancement in food gels: Effect of fracture properties on oral breakdown, bolus formation and sweetness intensity. Food Hydrocolloids, vol. 43, p. 794-802. https://doi.org/10.1016/j.foodhyd.2014.08.009

Mutiara, E., Adikahriani, Wahidah, S. 2012. Pengembangan formula biskuit daun katuk untuk meningkatkan ASI (Development of katuk leaf biscuit formula to increase breast milk). (In Indonesian) Available at: http://digilib.unimed.ac.id/19945/1/Fulltext.pdf

Noviyanti, Wahyuni, S., Syukri, M. 2016. Analisis penilaian organoleptik cake brownies subtitusi tepung wikau maombo (Analysis of organoleptic assessment of cake brownies substituted with maombo wikau flour). Jurnal Sains dan Teknologi Pangan, vol. 1, no. 1, p. 58-66. (In Indonesian)

Pratiwi, Y. F., Sulchan, M., Afifah, D. N., Rauf, R. 2021. Amino acids in enteral formula based on local fermented food for children with protein energy malnutrition. Potravinarstvo Slovak Journal of Food Sciences, vol. 15, p. 254-261. https://doi.org/10.5219/1480

Rahmayanti, E. A., Ningtyias, F. W., Baroya, N. 2020. Kadar protein, zat besi dan uji kesukaan sosis tempe dengan penambahan tepung daun kelor (Moringa oleifera) (Protein content, iron and tempeh sausage preference test with the addition of Moringa leaf flour (Moringa oleifera)). Ilmu Gizi Indonesia, vol. 4, no. 1, p. 29-38. (In Indonesian) https://doi.org/10.35842/ilgi.v4i1.153

Rauf, R. 2015. Kimia pangan (Food Chemistry). Yogyakarta, Indonesia : Andi, 256 p. (In Indonesian) ISBN9789792952032.

Romagny, S., Ginon, E., Salles, C. 2017. Impact of reducing fat, salt and sugar in commercial foods on consumer acceptability and willingness to pay in real tasting conditions: A home experiment. Food Quality and Preference, vol. 56, p. 164-172. https://doi.org/10.1016/j.foodqual.2016.10.009

Santoso. 2009. Susu dan yoghurt kedelai (Soy milk and yogurt). (In Indonesian) Available at: https://abfpuwg.files.wordpress.com/2010/02/susu-danyoghurt-kedelai

Setyaningsih, D., Apriyantono, A., Sari, M. P. 2010. Analisis sensori : untuk industri pangan dan agro (Sensory analysis: for the food and agro industry). Bogor, Indonesia : IPB Press, 180 p. (In Indonesian) ISBN-978-979-493-216-2.

Sinesio, F., Saba, A., Peparaio, M., Civitelli, E. S., Paoletti, F., Moneta, E. 2018. Capturing consumer perception of vegetable freshness in a simulated real-life taste situation. Food Research International, vol. 105, p. 764-771. https://doi.org/10.1016/j.foodres.2017.11.073

Sja'bani, M. 2015. Dahsyatnya tuma'ninah dalam sholat (gerakan peregangan khusus bersama pemahaman bacaan sholat) ulasan kesehatan fisik dan kesehatan hati (The power of tuma'ninah in prayer (special stretching movements with understanding of prayer readings) reviews physical health and heart health). Yogyakarta, Indonesia : PT Leutika Nouvalitera. (In Indonesian) 
Soekarto, S. T. 2012. Penelitian organoleptik untuk industri pangan dan hasil pertanian (Organoleptic research for the food and agricultural products industry). Yogyakarta, Indonesia : Liberty. (In Indonesian)

Subekti, K. 2004. Pengaruh asupan keong emas terhadap kadar hormon paratiroid pada penderita gagal ginjal kronik dengan hemodialisis rutin (Effect of golden snail intake on parathyroid hormone levels in patients with chronic kidney failure with routine hemodialysis). Department of Medicine in the Faculty of Medicine, Yogyakarta, Indonesia : Gadjah Mada University. 57 p. (In Indonesian)

Tauferova, A., Tremlova, B., Bednar, J., Golian, J., Zidek, R., Vietoris, V. 2015. Determination of ketchup sensory texture acceptability and examination of determining factors as a basis for product optimization. International Journal of Food Properties, vol. 18, no. 3, p. 660-669. https://doi.org/10.1080/10942912.2013.853186

Tur, J. A., Bibiloni, M. M. 2016. Functional foods. In Caballero, B., Finglas, P. M., Toldrá, F. Encyclopedia of Food and Health. Cambridge, USA : Academic Press, p. 157-161. https://doi.org/10.1016/B978-0-12-384947-2.00340-8

Utami, C. P., Fitrianingrum, S. A., Haryani, K. 2012. Pemanfaatan iles-iles (Amorphopallus oncophylus) sebagai bahan pengenyal pada pembuatan tahu (Utilization of iles-iles (Amorphopallus oncophyllus) as a thickening agent in the manufacture of tofu). Jurnal Teknologi Kimia dan Industri, vol. 1, no. 1, p. 79-85. (In Indonesian) Available at: https://ejournal3.undip.ac.id/index.php/jtki/article/view/36 8

Winarno, F. G. 2002. Kimia pangan dan gizi (Food chemistry and nutrition). Jakarta, Indonesia : Gramedia Pustaka Utama, 253 p. (In Indonesian) ISBN-9796860171.

\section{Funds:}

Support funding from The Ministry of Research, Technology, and Higher Education of the Republic of Indonesia, in the program of "Penelitian Disertasi Doktor", Project No. 2072/UN1/DITLIT/DIT-LIT/PT/2020.

\section{Acknowledgments:}

Thanks are conveyed to the staff of Klinik Bahasa at the Office of Research and Publication, Faculty of Medicine, Public Health, and Nursing, Universitas Gadjah Mada for proofreading the manuscript.

\section{Conflict of Interest:}

The authors declare no conflict of interest.

\section{Ethical Statement:}

This study obtained ethical clearance from the Ethical Commission of the Faculty of Medicine, Public Health, and Nursing, Universitas Gadjah Mada, Indonesia, with Ref. No.: KE/FK/0989/EC/2019.

\section{Contact Address:}

*Fery Lusviana Widiany, Gadjah Mada University, Faculty of Medicine, Public Health and Nursing, Doctoral Program of Medical and Health Science, Farmako Street, North Sekip, Yogyakarta, 55281, Special Region of Yogyakarta, Indonesia; Universitas Respati Yogyakarta, Faculty of Health Science, Department of Nutrition, Tajem Street Km.1.5, Maguwoharjo, Depok, Sleman, 55282, Special Region of Yogyakarta, Indonesia, Tel.:+62 85702024636,

E-mail: lusviana86@gmail.com

ORCID: https://orcid.org/0000-0002-0960-1705

Mochammad Sja'bani, Gadjah Mada University, Faculty of Medicine, Public Health and Nursing, Department of Internal Medicine, Farmako Street, North Sekip, Yogyakarta, 55281, Special Region of Yogyakarta, Indonesia, Tel.: +62 811282830,

E-mail: msbani jogja@yahoo.com

ORCID: https://orcid.org/0000-0002-0436-5846

Susetyowati, Gadjah Mada University, Faculty of Medicine, Public Health and Nursing, Department of Health Nutrition, Farmako Street, North Sekip, Yogyakarta, 55281, Special Region of Yogyakarta, Indonesia, Tel.: +62 818277781,

E-mail: susetyowati@ugm.ac.id

ORCID: https://orcid.org/0000-0002-3990-6403

Emy Huriyati, Gadjah Mada University, Faculty of Medicine, Public Health and Nursing, Department of Health Nutrition, Farmako Street, North Sekip, Yogyakarta, 55281, Special Region of Yogyakarta, Indonesia, Tel.: +62 81578756030,

E-mail: emyhuriyati@ugm.ac.id

ORCID: https://orcid.org/0000-0003-1785-5358

Corresponding author: * 